\title{
Word duration and grammatical and pragmatic function \\ - the case of egentlig
}

\author{
JAN HEEGÅRD
}

The article investigates variation in the duration of the pronunciation of the Danish adverb egentlig in a large corpus of spoken modern Danish. The article shows that there is considerable variation in the duration of egentlig, and that this variation only to some extent can be explained by speech rate (or 'articulation rate'). It is shown that the individual speaker has a significant impact on the variation. By the use of a mixed-model multiple linear regression analysis that incorporates the effect on duration that the individual speaker has, the investigation reveals that linguistic factors such as topology and utterance-final position together with factors relating to linguistic processing such as articulation rate and the position near a hesitation marker as well as nonlinguistic factors such as age and gender all contribute significantly to the variation in the duration of egentlig. The results are discussed in relation to similar findings in the literature and the article proposes potential future topics of investigation in relation to phonetic reduction in spoken Danish in the basis of the results. 